International Journal of

Engineering Education (IJEE)

e-ISSN : $2540-9808$

\title{
Analysis the Influence of Integration PKM-P, PKM-KC and PKM-T in Subjects Writing Techniques and Presentation on the Execution Time of the Final Project in Mechanical Engineering Diponegoro University
}

\author{
Norman Iskandar ${ }^{1}$, Rifky Ismail ${ }^{1}$, Friady Gumilar ${ }^{1}$ \\ ${ }^{1}$ Department of Mechanical Engineering, Diponegoro University, Jl. Prof. Sudharto SH, Tembalang, Semarang \\ 50275, Indonesia
}

Email: norman.undip@gmail.com

\begin{abstract}
This research is motivated by the study period of Mechanical Engineering students in UNDIP that is still quite long, more specifically dealing with the execution time of the Final Project (FP) that still quite long compared to the average in other departments in the Faculty of Engineering of Diponegoro University. Students can take the FP if it has to pass at least $115 \mathrm{credits}$ from total of 144 credits, and with a GPA above 2.25. Final project is a compulsory subject in 7 th semester, but most of the students can pick them up in 8 th to 10th semester. The final task takes time because nearly three months is required to be able to get a topic and a supervisor, the details of which one month process of signing up to the FP coordinator and the distribution of students into groups of KBK (there are four KBK), one month distribution process in the KBK to determine the FP lecturers and one month for the initial interaction with the FP lecturers. Problems in the FP including the theme / topic of the final project, the cost and process of making proposals, and the final report. The objectives of this research is to build synergies between the Writing Techniques and Presentation subject in the 6th semester with the FP subject in the 8th semester by using the momentum of PKM in the 7th semester. This study also aims to improve the quality of the final project, such as issues related time on KBK election, election supervisor FP, FP election topics, funding for FP workmanship as well as shortening the time to write a proposal and the final report. It is expected to shorten the FP program and the study period. This research is a class act. The planned action is integrating PKM in lectures Writing and Presentation Techniques in 6th semester. The planned action is integrating PKM in Writing Techniques and Presentation lectures in 6th semester. The planned action is integrating PKM in Writing Techniques and Presentation lectures in 6th semester. So that the output of the lectures of writing and presentation technique is to make a FP proposal to level ready for seminar and convert FP proposal into PKM until ready submitted to DIKTI. Subjects were students of S1 Mechanical Engineering UNDIP in the 6th semester. The research objects is Writing techniques and Presentation lectures. Stages of research include: preparation, planning, action, reflection. From the results of the study with a sample of students as many as 33 people showed for the evaluation of short-term target success rate of $80 \%$ PKM proposal ready to submit and FP proposals ready for a seminar, the achievements obtained was 100\% of students have successfully made a proposal FP and PKM with the guidance of lecturer KBK selected. From all proposals PKM and FP that have been made, as many as 10 titles PKM proposal meets the standards to be sent to the DIKTI and as many as 17 titles FP proposal is a direct recommendation from lecturers.
\end{abstract}

Keywords: The Study Period, The Final Project, PKM, Technical Writing, Presentations, Class Act.

Submission: August 1, 2018 Correction: November 27, 2018

Accepted: April 22, 2019

Doi: http://dx.doi.org/10.12777/ijee.1.1.24-30

[How to cite this article: Iskandar, N., Ismail, R., Gumilar, F. (2019), Analysis the Influence of Integration PKM-P, PKM-KC and PKM-T in Subjects Writing Techniques and Presentation on the Execution Time of the Final Project in Mechanical Engineering Diponegoro University. International Journal of Engineering Education, 1(1), 24-30. doi: http://dx.doi.org/10.12777/ijee.1.1.24-30]

\section{INTRODUCTION}

This research is motivated by the study period of Mechanical Engineering students in UNDIP that is still quite long, more specifically dealing with travel time of the Final Project (FP) that still quite long compared to the average in other departments in the Faculty of Engineering of Diponegoro University. Students can take the FP if passed at least 115 credits from total of 144 credits, and with a GPA above 2.25. Final project is a compulsory subject in 7 th semester, but most of the students can pick them up in 8th to 10th semester. The final project takes time because nearly three months is required to be able to get a topic and a supervisor, the details of which one month process of signing up to the FP coordinator and the distribution of students into groups of KBK (there are four KBK), one month 
distribution process in the KBK to determine the FP lecturers and one month for the initial interaction with the FP lecturers. Problems related to FP is the theme / topic of the final project, the cost of FP and the final project proposal process and the final report.

The raw materials of students in Department of Mechanical Engineering seen from the data ranking passing grade for new admissions, including a high position. This would suggest that the average quality of students entering good enough. However, different conditions will be encountered when the graduation, students of S1 Mechanical Engineering UNDIP has occupied the bottom position in the average GPA and the average length of study.

Some hypothesis about the cause of this problem includes courses in Mechanical Engineering are considered difficult because of applying the concept of multilevel courses/conditional. So that if it fails in one basic course it will be difficult to understand subjects sequel. The solution that taken from this condition is subject that heavy enough to understand opened in each semester.

Another hypothesis is that the existing classes too large capacity and inadequate means of support. The solution is taken to design a new room with a standard capacity.

The strategies is taking credits by students are less precise, especially in the 3rd to 6th semester is often a scourge. Euphoria high GPA in 1st and 2nd semester make students attempt to extract the maximum credits 24. Whereas in the 3rd semester students start receiving basic mechanics courses where science is far different from the first half and the second is partly a review high school lessons. The solution is taken is to teach students about the selection of subjects in 3rd to 6th semesters.

Another academic inhibitor is non-academic activities such as HMM very busy in the 2nd to 6th semester. In the 2 nd to 6 th semester also many practical activities. Against these conditions, the solution is given by the practicum arrangement including technical reports and assistance. For the activities in HMM, the mechanism of licensing activity also in trim.

From some of these efforts are already noticeable improvement. College students participating in each class has a reasonable amount. Or mean fewer students who receive grades $\mathrm{D}$ and $\mathrm{E}$. Acquisition of credits on average last three batches were monitored by majors such as students in 2013, 2014 and 2015 showed an average gain SKS were passed in each semester improved. This is supported by the data of students who took the final project (FP) on time, e.g at 7 th semester is also growing. At least this is seen in students in 2012

From improving conditions there is still a record that is related to the length of FP is in the range of eight months to one year, and the data on the average number of students potentially DO (drop out) were constrained in the FP. in the sense of all courses can be completed, but they get failed to complete the FP.

There are various factors that could affect the continuity of the process and the quality of learning outcomes. Purwanto in 1990 there were two factors that affect the learning process and results. The first individual factors such as maturity is a person, aspects of growth and development of body and soul, intelligence or intelligence elements, and repeat the process of training, motivation and personal character traits from oneself. The second factor is external factors or beyond individual factors such as family factors, such as economic aspects, education in the family and the atmosphere in the family. In addition, there is a factor family of teachers and how they were teaching, tools and equipment means of learning / teaching, motivation of the social environment, and the opportunity [1].

Muhibbin Shah expressed about matching that elements of internal and external factors that affect learning. Besides these two factors Muhibin add one more factor that is learning approach. Internal factors according Muhibin Shah is a factor that comes from within the students as the students physical and spiritual factors. The external factor is environmental conditions outside the student. Factor learning approach (approach to learning), such as learning about the methods used by the students [2].

Yusman Wiyatmo, and others wrote about the constraints experienced by the students in the preparation of FP. Factors that constrain the final formulation is based on his study of them [3]:

a. Lacks supporting references and books available in the library.

b. Less full laboratory facilities. FP trouble getting problems.

c. Lacks knowledge of students on the procedure for the preparation of FP.

d. Lacks funding for research.

e. Students do not have your own computer.

f. Process guidance is less than optimal.

g. Their confusion in determining the title FP students.

h. Laziness students in doing FP.

i. Difficulties in data collection techniques, difficulties in data analysis.

j. Lacks knowledge of students about the problems FP.

k. Limitations owned student learning device.

l. Difficulties to meet with the supervisor.

m. The disagreements between the supervisor I and II.

n. Do not have the spirit in preparing the FP.

o. The difficulty in determining the method of research.

p. Student difficulties in managing time to work SP.

q. The flurry of teachers so difficult to be found for guidance.

r. The results of relevant research with limited SP.

s. In the context of the final project in Mechanical

Engineering Undip some existing problems such as:

1. Students can take the FP if it has to pass at least 115 credits of a total of 144 credits, and with a GPA above 2.25 today where these conditions can be met average students in semester VIII to $\mathrm{X}$.

2. FP-making process that takes time because nearly three months after the lecture begins, new students can tune in with his FP. Details of three months is one month registration process 
coordinator and FP in the draw students will enter in groups where the KBK (there are four $\mathrm{CBC}$ ), one month process of division in the Group of Expertise (KBK- Majors) and the first month is the beginning of a process of interaction with lecturers Final supervisor.

3. Post met with the supervisor of the problem encountered is the theme Final adjustments because sometimes students get KBK second choice. Besides, students are also sometimes not direct intense because they take courses in either new or improved.

4. Problems encountered at the beginning is a custom theme Final mostly from professors, so that from the outset the proposal process FP is often merely a prerequisite administration. Proposal may change in the implementation of FP workmanship.

5. In addition to the problems the theme / topic of thesis, still problem sometimes encountered students that construction costs Final. Although there have been a standard maximum charge fees often students do not prepare properly so constrained. So that the final project be delayed.

6. After the process of FP, the last obstacle is the process of making a final report because the proposal only as a means of administration, graduate student FP workmanship which takes a long time, will make a draft report from the beginning again. This adds to the processing time.

PKM or Student Creativity Program is a strategic program in Higher Education. PKM program which will lead in PIMNAS is a representation of the Tri Dharma College because there is exist an element of Education, Research and Community Service. The existence of PKM institutionalized well in a campus could be reflected on the reflection PKM that can be felt, seen and developed in the flow of daily activities on campus. PKM can go in and integrated into the courses, PKM can enter to the research and be a part or a whole in the activities of student thesis or final project. PKM can also enter to the student's community service that can be joined with KKN programs.

\section{METHODS}

In connection with efforts to accelerate time studies in Mechanical Engineering Department Diponegoro University, particularly in respect of future complete the final project, the CRP can be integrated as an important point in the course Writing and Presentation Techniques. Subjects Writing Techniques and Presentation held on the 6th semester while subjects Final Project in a package placed in the semester 8 . Subjects Writing and presentation techniques designed as courses to prepare students in doing the Job Training courses and Final Project courses mainly related technical proposal writing and the final report, as well as the ability to make a good presentation materials and become a reliable paper presenter. According to the GBPP and SAP courses Writing Technique and Presentation, concepts and methods of learning in this course is the concept of exposure, class discussions, presentations and structured assignments either individually or in groups. The learning process is divided into two terms, the first term before UTS with topics related to the procedure of writing scientific papers and the second term is after UTS with good presentation topics.

In a study in order to integrate PKM-P, PKM-KC and PKM-T in the course Writing and Presentation Techniques, researchers used the concept of classroom action research. The planned action is integrating PKM guide in the implementation of Technical Writing and Presentation lectures in 6th semester.

The planned action is integrating PKM in Writing Techniques and Presentation lectures in 6th semester. So that the output of the lectures of writing and presentation technique is to make a FP proposal to level ready for seminar and convert FP proposal into PKM until ready submitted to DIKTI. Subjects were students of S1 Mechanical Engineering UNDIP in the 6th semester. The research objects is Writing Techniques and Presentation lectures. Stages of research include: preparation, planning, action, reflection.

Class action is successful if the first action, $80 \%$ of the students have completed the FP proposal has been consulted with the supervisor and the second act is said to be a success if $80 \%$ of the students have completed PKM proposal that ready to submit. Some things that have been done, which is expected to have implications for the acceleration on the execution time of the students final project in Mechanical Engineering is:

1. A discussion method is more widely used than the exposure method. Most of lecture material will be made into simple modules such as on FP guidelines, Job Training and PKM and distributed online via facebook group subjects Writing Techniques and Presentation.

2. Students are given the task to dissect the format of PKM-P, PKM-KC and PKM-T and then try to make a proposal in accordance with the PKM guidelines.

3. The task groups (one group consisting of three students in accordance with the selected KBK). The task of the group is to discuss with the lecturer of the KBK that they are interested in consulting about the topic of the final project that can be taken by them.

4. Discussions in class changed the format to a discussion between groups of KBK as a consequence of the chosen field of students. This discussion as a means to make students understand the KBK in Mechanical Engineering of Diponegoro University and final projects that have been and will be developed in the KBK.

5. The Outcomes of the course before the UTS is a proposal PKM, and after UTS is a FP proposal, slide presentation of the FP proposal, as well as video presentations of students when presenting FP proposals.

Selection of the concept of learning by promoting a structured task, observation and discussion by reducing the exposure of the model is not without reason. Ability explore ideas, the ability to make good writing, the ability to make the appropriate report is a skill issue. So 
as to encourage students to read a lot, a lot of discussion and a lot of practice is a way to improve their skills in scientific work. Subject Writing Techniques and Presentation course is easy to understand in theory, but it is more difficult to be implemented for those who are unfamiliar, such as courses machine drawing.

\section{RESULTS AND DISCUSSIONS}

Research conducted in the classroom with students of composition as shown in Table 3.1 and Table 3.2. This course is a compulsory subject in the 6th semester (class of 2013).

Table 3.1: Technical Writing and Presentations Course Participants in Class A

\begin{tabular}{cccc}
\hline No & information & Amount & Class of \\
\hline 1. & New (B) & 43 & 2011,2012, \\
& & & $2013,2014,2015$ \\
2 & Repeating (U) & 5 & $2011,2012,2013$ \\
3 & Repair (P) & 2 & 2010,2011 \\
\cline { 1 - 2 } & Total amount & $\mathbf{5 0}$ & \\
\hline
\end{tabular}

Table 3.2: Composition of the Students with a Status "New (B)"

\begin{tabular}{ccc}
\hline No & information & Amount \\
\hline 1. & Class of 2011 & 1 \\
2 & Class of 2012 & 4 \\
3 & Class of 2013 & 33 \\
4 & Class of 2014 & 4 \\
5 & Class of 2015 & 1 \\
\hline & Total amount & $\mathbf{4 3}$ \\
\hline
\end{tabular}

From the data in table 3.2, the research will focus on the student's class of 2013 (33 students), who first took a course Writing and Presentation Techniques. The first stage of the study was to distribute questionnaires to students. In taking the questionnaire, one student is absent due to illness. So the total questionnaire participants is 32 students. The second stage after the completion of the questionnaire administration, then followed by examining the results of the questionnaire and followed by a class act. Recapitulation of the first questionnaire can be seen in Table 3.3 and Table 3.4.

Table 3.3: Summary of Questionnaire One

\begin{tabular}{ccccc}
\hline No & Information & Yes & No & Amount \\
\hline $1 . \quad \begin{array}{c}\text { In the 1st semester already } \\
\text { have a target when it will } \\
\text { pass and a certain GPA upon } \\
\text { graduation? }\end{array}$ & 26 & 6 & 32 \\
$2 \quad \begin{array}{c}\text { Do you know the number of } \\
\text { lecturers in the Department } \\
\text { of Mechanical Engineering } \\
\text { Undip and know them all? } \\
\text { Do you know the number } \\
\text { and names of lecturers and } \\
\text { Expertise Group (KBK) in } \\
\text { Mechanical Engineering } \\
\text { Undip? }\end{array}$ & 0 & 32 & 32 \\
& & & \\
& & & \\
& & & \\
&
\end{tabular}

4

5 How long is the average each lecturer? period of study students of Mechanical Engineering

Undip (more than 5 years?) When will the average student taking FP undip engine $\left(8^{\text {th }}\right.$ semester or more)

$7 \quad$ In the 6th semester, do you feel it's time students start seriously thinking about FP? When students of Mechanical Engineering Undip ideal start seriously thinking about FP (7th semester or less)?

9 How much time do you think the ideal time to work on FP (6 months)?

10 How long is approximately the time you need to create a good draft FP (1 month)?

Table 3.4: Key Factor in Starting Final Project

\begin{tabular}{ccc}
\hline No & Considerations to Start TA & $\begin{array}{c}\text { Students } \\
\text { Choosing }\end{array}$ \\
\hline 1. & Lecturer & 10 \\
2 & KBK & 17 \\
3 & Final Project Title & 1 \\
4 & Cost & 1 \\
5 & Friends aor partner & 0 \\
6 & Difficulty / duration FP & 4 \\
\hline & Amount & $\mathbf{3 2}$ \\
\hline
\end{tabular}

From the data in Table 3.1 to Table 3.4 it can be concluded that the conditions in class $\mathrm{A}$, in the course of Writing Techniques and Presentation, for the sixth semester students (class of 2013) who first take Writing Techniques and Presentation courses is as follows:

1. In the 6th semester, yet all students $(68.75 \%$ to $81.25 \%$ ) recognized lecturers, knowing specification expertise, and in what KBK the lecturers join. In the Department of Mechanical Engineering Undip there are four groups of skills (KBK), namely; Materials, Production, Energy Conversion and Design.

2. In the 6th semester, as many as 25 of the 32 students, or about $78.13 \%$ of 32 students have an understanding that the courses FP average taken in semester 8 . As many as 27 students (84.38\%), felt that the ideal time start thinking about FP is in the semester 6 , and in the 8th semester is a delay.

3. All students $(100 \%)$ stated that ideally the process of FP is six months where one month in it is to work on FP report.

4. The main factor to be considered a student, to start the FP is when students were able to get into Research Groups that they are interested in as many as 17 students (53.15\%). While factors can get lecturers they enjoy as many as 10 students (31.25\%). 
From the results of the evaluation of the first phase of the questionnaire, students are given the task to choose the Expertise Group individually and selecting lecturers they enjoy for their visit and consult about the topic Final and the research being done by the lecturer. This assignment results obtained from the data in Table 3.5 and Table 3.6.

Table 3.5: KBK and the Number of Active Lecturer in Mechanical Engineering

\begin{tabular}{cc}
\hline $\begin{array}{c}\text { Design and } \\
\text { Construction KBK }\end{array}$ & $\begin{array}{c}\text { Energy Conversion KBK } \\
\text { (11 lecturers) }\end{array}$ \\
\hline Material KBK & Procturers) \\
(6 lecturers) & (6 lecturers) \\
\hline
\end{tabular}

Table 3.6: KBK and Lecturers that Students Interested

\begin{tabular}{|c|c|c|c|}
\hline No & Lecturer Name* & KBK & $\begin{array}{l}\text { Students } \\
\text { Choosing }\end{array}$ \\
\hline 1. & Lecturer A & $\begin{array}{c}\text { Design and } \\
\text { Construction } \\
\text { KBK }\end{array}$ & 4 \\
\hline 2 & Lecturer B & $\begin{array}{c}\text { Design and } \\
\text { Construction } \\
\text { KBK }\end{array}$ & 9 \\
\hline 3 & Lecturer C & Material KBK & 7 \\
\hline 4 & Lecturer D & $\begin{array}{c}\text { Energy } \\
\text { Conversion KBK }\end{array}$ & 2 \\
\hline 5 & Lecturer E & $\begin{array}{c}\text { Energy } \\
\text { Conversion KBK }\end{array}$ & 1 \\
\hline 6 & Lecturer F & Production KBK & 5 \\
\hline 7 & Lecturer G & Production KBK & 4 \\
\hline 8 & Lecturer $\mathrm{H}$ & Production KBK & 1 \\
\hline \multicolumn{3}{|c|}{ Amount } & 33 \\
\hline
\end{tabular}

Students should consult with the faculty she chooses must be at least three times, and there should be a supporting document. Three things that they should discuss with the lecturer is about PKM topic, the topic of FP and FP proposal. Students should be able to explore topics from the lecturer concerned to be made subject PKM (only PKM-KC, PKM-P and PKM-T), the topic of FP and FP proposal. The results of this process as shown in Table 3.7

\section{Table 3.7: Evaluation of PKM and FP Topics of the} Students

\begin{tabular}{cccc}
\hline No & Information & Yes(Title) & No(Title) \\
\hline 1. & $\begin{array}{c}\text { Same topic (PKM } \\
\text { and FP) }\end{array}$ & 4 & 29 \\
2 & $\begin{array}{c}\text { PKM topics and FP } \\
\text { was given by } \\
\text { lecturer }\end{array}$ & 7 & 26 \\
$\quad \begin{array}{c}\text { Own initiative topic } \\
\text { (PKM) }\end{array}$ & 29 & 4 \\
4 & $\begin{array}{c}\text { Own initiative topic } \\
\text { (FP) }\end{array}$ & 16 & 17 \\
\hline
\end{tabular}

From the evaluation of the first questionnaire, the data obtained about the weakness of the student, while on assignment evaluation as listed in Table 3.7, shows that if the process is accelerated, it was not only the students who have to be changed, but the paradigm lecturers must also be changed. The condition where the students were enthusiastic about FP does not necessarily get the same response from lecturers who have been selected by the student. It is seen that not all lecturers would provide a direct topic for students in the 6 th semester which has been facing.

Some of the reasons that into consideration lecturer is, the students of the 6th semester, there are still many who have not reached the 100 credits, whereas FP requirement is 115 credits. Second, students do not yet know all the teachers, and the process does not have official ties in the system, so it could have the students will move on to other lecturers.

From the interviews in class some of the responses given by the lecturer chosen by students in starting FP by making a proposal PKM is as follows:

1. Provides an overview of discourse about PKM and FP done by lecturers and opportunities related titles that can be taken by students.

2. Provide an overview of the FP topic in progress and the potential titles for FP, but did not provide recommendations on PKM, because the lecturer is not so intense in PKM.

3. Ask the students to directly interact with senior students who are working on FP and allowing students to explore and FP and PKM topics, independently.

Post-evaluation, followed by a second questionnaire in which the recapitulation of the data obtained, shown in Table 3.8 and 3.9.

Table 3.8: Summary of Questionnaire Two

\begin{tabular}{|c|c|c|c|c|}
\hline No & Information & Yes & No & Amount \\
\hline 1. & $\begin{array}{l}\text { Before the lecture Writing } \\
\text { Techniques, did you ever, } \\
\text { read yours senior FP? }\end{array}$ & 17 & 15 & 32 \\
\hline 2 & $\begin{array}{l}\text { Before the lecture Writing } \\
\text { Techniques, if you already } \\
\text { know about the format of the } \\
\text { FP proposal and report? }\end{array}$ & 1 & 31 & 32 \\
\hline 3 & $\begin{array}{l}\text { Before you got Lectures } \\
\text { Writing Techniques and } \\
\text { Presentation, did you ever } \\
\text { make a } \boldsymbol{P K M} \text { proposal and } \\
\text { other scientific publications? }\end{array}$ & 19 & 13 & 32 \\
\hline 4 & $\begin{array}{l}\text { If the sixth semester you are } \\
\text { allowed to begin drafting FP } \\
\text { proposal and PKM proposal, } \\
\text { if it will help you speed up } \\
\text { the execution of FP? }\end{array}$ & 31 & 1 & 32 \\
\hline 5 & $\begin{array}{l}\text { If the sixth semester you are } \\
\text { allowed to choose the faculty } \\
\text { and the KBK to begin serious } \\
\text { work on FP, with the } \\
\text { consequence must make FP } \\
\text { proposal and PKM Proposal, } \\
\text { if it can help you in speeding } \\
\text { up the execution and } \\
\text { completion of the FP? }\end{array}$ & 32 & 0 & 32 \\
\hline
\end{tabular}


The important thing that the questionnaire can be obtained include:

1. Before taking courses in writing technique and presentation, in which there is an assignment to read and analyze the format of FP, was almost $50 \%$ of the students until the 6 th semester students have never read previous FP.

2. Almost all students in the 6th semester do not understand the format of writing proposals and FP reports correctly, whereas FP guideline can be downloaded at any time.

3. Almost $50 \%$ of 33 students have experienced in writing PKM, but the majority of the experience gained when a new student because it is semimandatory activities.

4. After one semester to try to make a PKM proposal, and FP proposal correctly, students feel a lot of flaws and experiencing a lot of trouble to make it. So that almost $100 \%$ of the students looked at if the course of writing techniques and presentation can be integrated in the execution of the FP where one component can choose KK and lecturers favored, they argue it could accelerate The FP progress, even if the requirements they have to make a proposal PKM's submitted to seek funding and make FP proposals.

\section{Table 3.9: The Most Difficult Factors in Making Proposal and Report}

\begin{tabular}{ccc}
\hline No & $\begin{array}{c}\text { The Most Difficult Factors in } \\
\text { Making Proposal and Report }\end{array}$ & $\begin{array}{c}\text { Students } \\
\text { Choosing }\end{array}$ \\
\hline 1. & Abstract & 5 \\
2 & Introduction & 6 \\
3 & Basic theory & 5 \\
4 & Research Metodologi \& flow & 4 \\
& $\begin{array}{c}\text { chart } \\
5\end{array}$ & 12 \\
& Analysis of the discussion and \\
6 & conclusions & \\
\hline & Bibliography and citation & 0 \\
\hline
\end{tabular}

From the evaluation of the questionnaire, the students looked at the highest difficulty is to provide an analysis of the discussion. Meanwhile, related to the writing of abstract, introduction, basic theory, flowcharts or research methodology and writing citations and a bibliography is no longer a major problem $(12 \%$ to $18 \%$ that regard is still a major problem). Somehow it has indicated that the targets of lectures on the topic quite successfully at the end of the lecture.

In closing, from a total of 33 students were evaluated, related to the PKM title and FP title that eligible, as well as the writing format that meets the standards of PKM reference and a FP reference, then there are 10 PKM titles of the 33 titles that were evaluated, eligible for directly submitted to DIKTI for 2017 funding. For FP, there are 17 titles that directly recommended by lecturers, but in terms of content, some are still lacking. This is understandable because they interact only one month, but in writing relatively feasible and acceptable. This is certainly an encouraging point if in the end the 10-17 PKM and FP titles, will go straight to the more serious process, so that $50 \%$ of participant's lectures in class A does not need to follow the process of KBK and lecturers distribution on FP lecture, where it takes about two months from the start of the lecture period.

Short-term evaluation to determine success or failure class actions have been implemented. This was done after the questionnaires one and two questionnaires. Mid-term evaluation is currently PKM submit to the DIKTI, which has been selected proposals are being prepared for the submitted. Long-term evaluation carried out during the announcement of PKM funded or grant-funded research and also at the end of the course, when students graduate. Follow-up of this study will continue until graduation.

From the short-term indicators of success that has been specified in the research proposal, which achieved at least $80 \%$ of students participating in the study has made a final project proposal, and $80 \%$ PKM proposals ready to submit, has not been achieved. The achievement of the target only about $50 \%$. It is caused by one of the factors that were previously less predictable, e.g the readiness of lecturers as the reference selection 6th semester students, in assisting students to make FP proposals and PKM proposals. Indicators of success of the medium-term is $100 \%$ of proposals made could be submitted, where it cannot be known because of not having opened the registration process PKM funding in 2017. Indicators of long-term success is, $50 \%$ of proposals funded and 30 percent of students continue the topic into the final project will be known in 2017 .

\section{CONCLUSIONS}

From the results of the study, with a sample of students as many as 33 people showed for the evaluation of short-term target success rate of $80 \%$ PKM proposal ready to submit and FP Proposals ready for a seminar, the achievements obtained was $100 \%$ of students have successfully made a FP and PKM proposals with gets guidance from the lecturers selected. From all PKM and FP proposals PKM that have been made, after doing review it earned 10 titles PKM proposal meets the standards for directly submitted to DIKTI. As for the FP proposal as many as 17 as titles are titles that directly recommended by the lecturer. The conclusion is:

1. More than $50 \%$ of 33 students get feedback is expected, e.g. given PKM and FP topic from the lecturers of the KBK that they select.

2. $100 \%$ college students have successfully made a FP proposal.

3. FP funding is no longer a major problem in completing the final project.

An increasing number of proposals that are ready to be sent to DIKTI, which is $50 \%$ of the total students in the classroom.

\section{Suggestion}

1. It takes the same questionnaire for lecturers.

2. Involving students in other classrooms in Subjects Writing and Presentation Techniques in order to better study results. 


\section{Acknowledgments}

The author wishes to thank to the Engineering Faculty of Diponegoro University for the funding of this research

\section{REFERENCES}

[1] Purwanto, M.N. 1990. Psikologi Pendidikan. PT Remaja Rosdakarya. Bandung.

[2] Muhibbin Syah. 1997. Psikologi Pendidikan: Dengan Pendekatan Baru. Remaja Rosdakarya.Bandung.

[3] Wiyatmo, Yusman. Munilarto. Suharyanto \& Widodo, Eko. 2010. Efektifitas Bimbingan Tugas Akhir Skripsi (TAS) Mahasiswa Jurusan Pendidikan Fisika FMIPA UNY. Prosiding Seminar Nasional Penelitian, Pendidikan dan Penerapan MIPA. Fakultas MIPA UNY. Yogyakarta. 